\title{
PENGARUH MODEL PEMBELAJARAN CIRC TERHADAP KEMAMPUAN MENYELESAIKAN SOAL CERITA MATERI SPLDV KELAS VIII
}

\author{
Rusmala Dewi ${ }^{1}$, Elhefni ${ }^{2}$, Gusmelia Testiana ${ }^{3}$ \\ Universitas Islam Negeri (UIN) Raden Fatah Palembang \\ email: rusmala_dewi@ymail.com \\ email: abifarhan1973@gmail.com \\ email: gusmelia.testiana@gmail.com
}

\begin{abstract}
The objective of this research is to investigate the learning model which contributes to the ability to solve the story questions better between the learning model of the Cooperative Integrated Reading and Composition and the conventional one. Sampling condused in purposive sampling. The samples of the research were 67 students of two class, namely: 33 students of class A as experiment group and 34 students of class $B$ as control group. In the learning process, the former used the learning model of Cooperative Integrated Reading and Composition where as the latter used the conventional one. The instruments used to gather the data of the research were subjective tests of 4 essay questions. The data of the research use test techniques. The data were then analyzed by using the t test. Normality test using Lilliefors method, homogeneity test using Fisher method, and hypothesis test using $t$ test. Based on final data processing (post-test score) shows that the average score of the experiment group is 88, where as that of the control group is 72,64. The result of the t test at the significance level of 0.05 , the value of tcount $=7,539$ is greater than that of ttable $=$ 1,999, meaning that $H_{o}$ is rejected, and $H_{a}$ is verified.

Based on the results of the research, a conclusion is drawn that the use of the Cooperative Integrated Reading and Composition in the ability to solve the story is better than that of the conventional one.
\end{abstract}

Keywords : Cooperative Learning Model Type CIRC, Story Question.

\footnotetext{
${ }^{1}$ Alumni UIN Raden Fatah Palembang

23 Dosen UIN Raden Fatah Palembang
} 


\begin{abstract}
ABSTRAK
Tujuan penelitian ini adalah mengetahui model pembelajaran yang memberikan kemampuan menyelesaikan soal cerita yang lebih baik di antara model pembelajaran Cooperative Integrated Reading and Composition (CIRC) atau model pembelajaran konvensional. Penelitian ini menggunakan metode penelitian eksperimen. Instrumen yang digunakan dalam penelitian ini berupa tes subjektif uraian sebanyak 4 soal uraian. Teknik pengambilan sampeldilakukan secara Purposive Sampling. Sampel yang digunakan dalam penelitian ini sebanyak 67 siswa, dengan perincian siswa kelas VIII.A sebagai kelompok eksperimen dengan jumlah siswa 33 anak, dan siswa kelas VIII.B sebagai kelompok kontrol dengan jumlah 34 orang. Dalam pembelajarannya, kelompok eksperimen menggunakan model pembelajaran Cooperative Integrated Reading and Composition, sedangkan kelompok kontrol menggunakan model pembelajaran konvensional. Pengumpulan data dalam penelitian menggunakan teknik tes. Uji normalitas menggunakan metode Lilliefors, uji homogenitas menggunakan metode Fisher, dan uji hipotesis dengan uji t. Berdasarkan hasil pengolahan data akhir (posttest) diperoleh nilai rata-rata kelompok eksperimen sebesar 88 dan rata-rata kelompok kontrol sebesar 72,64. Pada hasil uji dengan taraf signifikansi 0,05. nilai $t_{\text {hitung }}=7,539$ $>\mathrm{t}_{\text {tabel }}=1,999$, ini berarti $H_{o}$ ditolak dan $H_{a}$ diterima. Simpulan penelitian ini adalah kemampuan menyelesaikan soal cerita pada pokok bahasan sistem persamaan linear dua variabel dengan menggunakan model pembelajaran Cooperative Integrated Reading and Composition lebih baik dari pada menggunakan model pembelajaran konvensional.
\end{abstract}

\title{
Kata kunci : Model Cooperative Learning tipe CIRC, Soal Cerita.
}

\section{PENDAHULUAN}

Matematika merupakan pengetahuan yang mempunyai peran sangat besar, baik dalam kehidupan sehari-hari maupun dalam pengembangan ilmu pengetahuan lain. Matematika merupakan salah satu mata pelajaran yang selalu diajarkan pada bidang pendidikan baik pada pendidikan dasar, menengah bahkan sampai dijenjang perguruan tinggi.

Dalam Depdiknas (2007:4), beberapa tujuan mempelajari matematika antara lain agar siswa memiliki kemampuan memahami konsep matematika secara luwes, akurat, efisien, dan tepat dalam memecahkan masalah, serta memiliki sikap menghargai kegunaan matematika dalam kehidupan, yaitu memiliki rasa ingin tahu, perhatian dan minat dalam mempelajari matematika, sikap ulet dan percaya diri dalam menyelesaikan masalah.

Kemampuan menyelesaikan masalah matematika pada siswa dapat diketahui melalui soal-soal yang berbentuk uraian. Dengan adanya soal yang berbentuk uraian, dapat dilihat langkah-langkah yang dilakukan siswa dalam 
menyelesaikan suatu permasalahan. Salah satu soal uraian dalam matematika berupa soal cerita.

Soal cerita adalah soal yang terbatas pada persoalan sehari-hari (Hudojo,2005:25). Soal cerita banyak ditemukan dalam setiap pembahasan materi karena merupakan contoh penerapan dalam kehidupan sehari-hari. Soal cerita merupakan modifikasi dari soal hitungan yang dibuat kedalam cerita pendek. Penyajian soal dalam bentuk cerita adalah salah satu upaya untuk menerapkan konsep yang sedang dipelajari sesuai dengan pengalaman sehari-hari siswa. Kemampuan siswa dalam menyelesaikan masalah soal cerita dapat dilihat dari perolehan hasil belajar. Selain itu juga dapat dilihat bagaimana proses siswa menyelesaikan soal tersebut sampai menemukan jawaban yang benar.

Kemampuan siswa dalam menyelesaikan soal cerita matematika dapat dilihat dari beberapa indikator, yaitu kemampuan memahami dan menangkap makna dalam soal cerita matematika, kemampuan memisahkan dan mengungkapkan apa yang diketahui dan ditanya, kemampuan menggunakan rumus yang sesuai dengan apa yang ditanyakan, dan kemampuan menyelesaikan pehitungan dengan rumus yang sesuai (Hudojo,2005:27). Jadi dapat disimpulkan bahwa seorang siswa dikatakan mampu menyelesaikan soal cerita jika ia mampu memahami apa yang ditanyakan dalam soal, dapat merubahnya dalam bentuk penyelesaian matematika dan memilih strategi yang tepat untuk menyelesaikannya.

Namun pada kenyataannya, kemampuan menyelesaikan soal cerita matematika siswa kelas VIII di MTs Ahliyah 1 Palembang masih terbilang rendah, hal ini dilihat dari rendahnya hasil belajar siswa pada materi sebelumnya. Pada materi tersebut, khususnya soal dalam bentuk cerita rata-rata siswa mendapatkan nilai 60 padahal ketuntasan minimal pada pelajaran matematika yaitu 75 .

Dari hasil observasi yang dilakukan di kelas VIII MTs Ahliyah 1 Palembang diperoleh data 60\% siswa kelas VIII MTs Ahliyah 1 Palembang kurang menyukai soal cerita. Dan hasil wawancara yang dilakukan pada tanggal 30 Maret 2016 dengan Ibu Tia Utari, S.Pd. selaku guru mata pelajaran matematika kelas VIII di MTs Ahliyah 1 Palembang didapatkan bahwa, faktor ketidakmampuan siswa dalam menyelesaikan soal cerita yaitu siswa kurang dapat memahami maksud dari soal 
cerita tersebut, siswa kesulitan mengubah bentuk soal cerita ke dalam model matematika.

Dari uraian di atas dapat disimpulkan, bahwa yang membuat siswa kurang mampu dalam menyelesaikan soal cerita dikarenakan siswa tidak memahami maksud dari soal cerita tersebut. Hal ini karena siswa malas membaca, sulit memahami soal, tidak tahu langkah yang dilakukan terlebih dahulu karena soal dirasa terlalu rumit. Untuk itu upaya perencanaan pembelajaran inovatif dengan menggunakan strategi efektif terhadap kemampuan menyelesaikan soal cerita matematika perlu dilakukan.

Salah satu upaya yang dapat dilakukan yaitu dengan menerapkan suatu model pembelajaran kooperatif yang dapat membantu mengatasi permasalah di atas. Salah satu model pembelajaran kooperatif tersebut yaitu tipe pembelajaran Cooperative Integrated Reading and Composition (CIRC).

Model pembelajaran kooperatif tipe Cooperative Integrated Reading and Composition (CIRC) merupakan sebuah program pemahaman membaca dan menulis pada tingkat dasar, menengah, dan atas (Slavin, 2005:200). Oleh karena itu pada penelitian ini menggunakan model pembelajaran kooperatif tipe Cooperative Integrated Reading and Composition (CIRC) sebagai salah satu solusi untuk meningkatkan kemampuan siswa dalam menyelesaikan soal cerita. Dalam pembelajaran matematika, kegiatan dalam model pembelajaran kooperatif tipe Cooperative Integrated Reading and Composition (CIRC) tidak hanya membaca dan menuliskan inti dari bacaan, akan tetapi siswa dituntut untuk menyelesaikan soal cerita kedalam bentuk perhitungan matematika untuk memperoleh jawaban yang tepat.

Adapun materi yang dipilih dalam penelitian ini yaitu materi Sistem Persamaan Linear Dua Variabel (SPLDV), karena pada materi tersebut banyak menggunakan soal cerita yang menuntut siswa untuk bisa menyelesaikannya. Terlebih lagi kendala dari materi ini yaitu mengubah soal cerita kedalam bentuk matematika, yang mana untuk bisa menyelesaikan permasalahn dalam bentuk cerita siswa harus mengubahnya terlebih dahulu kedalam model matematikanya. 


\section{METODOLOGI PENELITIAN}

Jenis metode penelitian yang digunakan dalam penelitian ini adalah penelitian kuantitatif dengan metode eksperimen karena penelitian ini diberikan suatu perlakuan (treatment) untuk mengetahui hubungan antara perlakuan tersebut dengan aspek tertentu yang akan diukur. Desain eksperimen dalam penelitian ini adalah True Experimental Design (eksperimen yang betul-betul) kategori Posttest-Only Control Design. Dalam desain ini terdapat dua kelompok yang dipilih secara random. Kelompok pertama diberikan perlakuan (X) yaitu pembelajaran matematika dengan menggunakan model pembelajaran kooperatif tipe Cooperative Integrated Reading and Composition (CIRC), kedua diberikan pembelajaran dengan metode konvensional. Kelompok yang diberikan perlakuan disebut kelompok eksperimen dan kelompok yang tidak diberikan perlakuan disebut kelompok kontrol.

Sampel penelitian ini adalah siswa kelas VIII MTs Ahliyah 1 Palembang pada semester ganjil tahun ajaran 2016/2017. Pemilihan sampel pada penelitian ini menggunakan Purposive Sampling. Untuk kelas eksperimen dipilih kelas VIIIA dan kelas kontrol yaitu kelas VIIIB.

\section{a. Prosedur Penelitian}

Prosedur penelitian dilakukan dengan tahap-tahap sebagai berikut:

1) Tahap Perencanaan

2) Tahap pelaksanaan penelitian

Peneliti melaksanakan kegiatan pembelajaran matematika dengan menerapkan model pembelajaran kooperatif tipe Cooperative Integrated Reading and Composition (CIRC).

a) Mengelompokkan subjek penelitian menjadi dua kelompok yaitu kelas eksperimen dan kelas kontrol.

b) Pertemuan pertama, kedua, ketiga, dan keempat peneliti memberikan pembelajaran menggunakan model pembelajaran kooperatif tipe Cooperative Integrated Reading and Composition (CIRC). Pada kelas eksperimen yang telah ditentukan. Sedangkan kelas kontrol menggunakan model pembelajaran langsung (konvensional) dengan metode ceramah dan pemberian tugas. 
c) Pertemuan kelima, memberikan tes akhir (posttest) di kelas eksperimen atau kelas kontrol untuk mengukur keterampilan siswa dalam menyelesaiakn soal cerita setelah digunakan model pembelajaran kooperatif tipe Cooperative Integrated Reading and Composition (CIRC)..

\section{3) Tahap Pelaporan}

Langkah-langkah yang akan dilakukan dalam tahap ini, yaitu sebagai berikut:

a) Menganalisis data yang diperoleh.

b) Mendeskripsikan hasil pengolahan data.

c) Menyusun laporan penelitian.

\section{b. Teknik Pengumpulan Data}

Teknik pengumpulan data pada penelitian ini adalah menggunakan tes. Tes dalam penelitian ini adalah tes tertulis dalam bentuk soal uraian yang digunakan untuk mengukur kemampuan siswa dalam menyelesaikan soal cerita. Tes yang digunakan dalam penelitian ini adalah postest dengan soal yang berupa tes uraian essay sebanyak 4 soal yang mengacu pada rubrik penilaian hasil penyelesaian soal cerita yang diberi skor sesuai dengan pedoman penskoran. Untuk memperoleh data hasil menyelesaikan soal cerita siswa dilakukan penskoran terhadap jawaban siswa untuk tiap butir soal. Kriteria penskoran yang digunakan dapat dilihat pada Tabel 1.

Tabel 1. Pedoman Penilaian kemampuan menyelesaikan Soal Cerita

\begin{tabular}{|l|l|l|}
\hline \multicolumn{1}{|c|}{ Indikator } & \multicolumn{1}{|c|}{ Reaksi terhadap soal } & skor \\
\hline $\begin{array}{l}\text { Memahami masalah : } \\
\text { kemampuan } \\
\text { mengidentifikasi unsur- } \\
\text { unsur yang diketahui, } \\
\text { ditanyakan dan kecukupan } \\
\text { unsur yang diperlukan }\end{array}$ & $\begin{array}{l}\text { Salah mengidentifikasikan unsur- } \\
\text { unsur yang diketahui, ditanyakan }\end{array}$ & 1 \\
\cline { 2 - 3 } & $\begin{array}{l}\text { Cukup memahami untuk memperoleh } \\
\text { bagian dari penyelesaian }\end{array}$ & 2 \\
\cline { 2 - 3 } $\begin{array}{l}\text { Membuat / menyusun } \\
\text { model matematika: } \\
\text { kemampuan merumuskan } \\
\text { masalah sehari-hari ke } \\
\text { dalam model matematika }\end{array}$ & $\begin{array}{l}\text { Semalah membuat model matematika } \\
\text { tidak lengkap }\end{array}$ & 3 \\
\cline { 2 - 3 } Membuat model matematika secara & 3 \\
\hline Memilih strategi pemecahan & Memilih strategi yang tidak relevan & 1 \\
\hline
\end{tabular}




\begin{tabular}{|c|c|c|}
\hline & $\begin{array}{l}\text { Memilih stategi yang tidak dapat } \\
\text { diselesaikan }\end{array}$ & 2 \\
\hline & $\begin{array}{l}\text { Memilih strategi pemecahan sesuai } \\
\text { dengan prosedur tetapi jawaban salah }\end{array}$ & 3 \\
\hline & $\begin{array}{l}\text { Memilih strategi pemecahan sesuai } \\
\text { dengan prosedur dan jawaban benar }\end{array}$ & 4 \\
\hline $\begin{array}{l}\text { Menjelaskan dan memeriksa } \\
\text { kebenaran jawaban }\end{array}$ & $\begin{array}{l}\text { Tidak menjelaskan dan tidak } \\
\text { memeriksa kebenaran jawaban }\end{array}$ & 1 \\
\hline & Ada penjelasan tetapi tidak benar & 2 \\
\hline & $\begin{array}{l}\text { Penjelasan benar tetapi tidak } \\
\text { memeriksa kebenaran jawaban }\end{array}$ & 3 \\
\hline & $\begin{array}{l}\text { Penjelasan benar dan memeriksa } \\
\text { kebenaran jawaban }\end{array}$ & 4 \\
\hline
\end{tabular}

\section{c. Variabel Penelitian}

Variabel dalam penelitian ini adalah variabel bebas dan terikat. Variabel bebas adalah variabel yang mempengaruhi atau yang menjadi sebab perubahannya atau timbulnya variabel dependent (terikat). Variabel terikat adalah variabel yang dipengaruhi atau yang menjadi akibat, karena adanya variabel bebas (Sugiyono, 2009:39). Variabel bebas dalam penelitian ini adalah model cooperative integrated reading and composition dan variabel terikat dalam penelitian ini adalah kemampuan menyelesaikan soal cerita.

\section{d. Teknik Analisis Data}

Teknik pengumpulan data pada penelitian ini adalah menggunakan tes posttest. Dalam sebuah penelitian dibutuhkan instrumen penelitian yang baik agar hasil penelitian yang dilakukan akurat. Instrumen penelitian dikatakan baik jika memiliki tingkat validitas baik dan reliabilitas yang baik. Dalam penelitian ini, penulis menghitung koefisien validitas dengan menggunakan rumus korelasi product moment dengan angka kasar.

Hasil analisis perhitungan validitas butir soal $\left(r_{\text {hitung }}\right)$ lalu dilihat harga $\mathrm{r}$ product moment $\left(r_{\text {tabel }}\right)$ dengan taraf signifikan 5\%. Bila harga $r_{\text {hitung }}>r_{\text {tabel }}$ maka butir soal tersebut valid. Sebaliknya jika harga $r_{\text {hitung }}<r_{\text {tabel }}$ maka butir soal tersebut dikatakan tidak valid. Sedangkan untuk melihat tingkat reliabilitas instrument dalam penelitian ini menggunakan rumus Alpha. 
Untuk menafsir harga reliabilitas dari soal maka harga tersebut dikonsultasikan ke tabel harga kritik $r_{\text {tabel }}$ Product Moment dengan $\alpha=0,05$ dengan kriteria korelasi $r_{\text {hitung }}>r_{\text {tabel }}$ maka tes tersebut reliabel.

Setelah diperoleh data dari hasil posttest selanjutnya akan dilakukan analisis data untuk menguji hipotesis yang telah dirumuskan sebelumnya melalui uji prasyarat sebagai berikut:

a) uji Normalitas data dengan menggunakan uji Liliefors. Hasil akhir pengujian data dengan uji Liliefors ini yaitu dengan menarik kesimpulan berdasarkan harga $\mathrm{L}_{0}<\mathrm{L}_{\mathrm{t}}$, maka sampel berasal dari distribusi normal

b) Uji Homogenitas dengan uji kesamaan varians atau uji F; Jika $F_{\text {hitung }}<$ $\mathrm{F}_{\text {tabel, }}$ maka $\mathrm{H}_{\mathrm{o}}$ diterima (homogen) dan $\mathrm{H}_{\mathrm{a}}$ ditolak. Jika $\mathrm{F}_{\text {hitung }}>\mathrm{F}_{\text {tabel }}$, maka $\mathrm{H}_{\mathrm{o}}$ ditolak dan $\mathrm{H}_{\mathrm{a}}$ Diterima.

c) Uji Hipotesis dengan menggunkan uji t. $H_{o}$ diterima jika $t_{\text {hitung }}<t_{\text {tabel }}$ dan $\mathrm{H}_{\mathrm{o}}$ ditolak jika $\mathrm{t}_{\text {hitung }}>\mathrm{t}_{\text {tabel. }}$

\section{HASIL DAN PEMBAHASAN}

\section{A. Hasil Penelitian}

\section{1) Deskripsi Kegiatan Penelitian}

Penelitian ini dilaksanakan di MTs Ahliyah 1 Palembang dimulai pada tanggal 6 Agustus 2016 s/d 29 Agustus 2016. Sebelum melaksanakan penelitian peneliti mempersiapkan instrumen penelitian yang selanjutnya dilakukan validasi kepada validator Instrumen penelitian yang disiapkan diantaranya Rencana Pelaksanaan Pembelajaran (RPP), soal posttest dan LKS.

Pada tahap perencanaan peneliti membuat instrumen penelitian berupa RPP, Posttest, dan LKS lalu instrumen tersebut divalidasi dengan tim pakar (Validator) untuk mendapatkan instrumen penelitian yang berkarakter valid. Pada tahap perencanaan ini juga peneliti melakukan observasi ke sekolah menemui guru yang bersangkutan untuk menanyakan jadwal dimulanya penelitian. Selanjutnya peneliti melakukan uji instrumen tes. 
Pada tahap pelaksanaan penelitian terdiri dari dua kelas yaitu kelas eksperimen dan kelas kontrol. Pelaksanaan penelitian dilaksanakan pada tanggal 6 Agustus 2016 s/d 29 Agustus 2016. Kelas VIIIA sebagai kelas eksperimen dan kelas VIIIB sebagai kelas kontrol di MTs Ahliyah 1 Palembang. Dalam proses pembelajaran kelas eksperimen diberi perlakuan menggunakan model pembelajaran cooperative integrated reading and composition, sedangkan kelas kontrol menggunakan pembelajaran metode konvensional. Pembelajaran dilaksanakan dalam 5 kali pertemuan dan 1 kali pertemuan tes akhir (posttest) masing-masing untuk kelas eksperimen dan kontrol.

Tahap pelaporan dimulai pada tanggal 30 Agustus 2016. Peneliti melakukan analisis data untuk menguji hipotesis dan menyimpulkan hasil penelitian yang dilaksanakan. Dari tahap pelaporan ini didapatkan sebuah kesimpulan untuk menjawab rumusan masalah.

\section{2) Deskripsi Hasil Validasi Instrumen Penelitian}

\section{a. Hasil Validasi oleh Pakar}

Sebelum melakukan penelitian, terlebih dahulu melakukan validasi instrumen penelitian, validasi ini digunakan untuk mendapatkan instrumen yang berkriteria valid. Adapun pembahasan mengenai hasil validasi instrumen penelitian adalah sebagai berikut:

\section{1) Rencana Pelaksanaan Pembelajaran (RPP)}

Saran yang diberikan oleh para validator mengenai kevalidan RPP dalam penelitian ini antara lain dapat dilihat tabel di bawah ini:

Tabel 2.

Komentar/Saran Validator

\begin{tabular}{|c|l|}
\hline Validator & \multicolumn{1}{|c|}{ Komentar/Saran } \\
\hline Riza Agustiani, M.Pd & a. RPP \\
(Dosen Matematika UIN Raden & $>\begin{array}{l}\text { Buat langkah model } \\
\text { pembelajaran dalam RPP }\end{array}$ \\
Fatah) & $>\begin{array}{l}\text { Sesuaikan penilaian dengan } \\
\text { indikator yang ingin dicapai }\end{array}$ \\
& $>$ Perbaiki soal pada penilaian \\
& hasil belajar \\
& b. LKS \\
& $>$ Sesuaikan soal-soal dengan \\
& indikator yang ingin dicapai \\
\hline
\end{tabular}




\begin{tabular}{|c|c|}
\hline & $\begin{array}{l}\text { Perbaiki redaksi kalimat } \\
\text { Sesuaikan dengan langkah } \\
\text { pemecahan masalah } \\
\text { c. Soal Posttest } \\
\text { Sesuaikan soal dengan } \\
\text { indikator yang ingin dicapai } \\
\text { Buat KPM untuk kisi-kisi } \\
\text { soal }\end{array}$ \\
\hline $\begin{array}{c}\text { Rieno Septra Nery, M.Pd } \\
\text { (Dosen Matematika UIN Raden } \\
\text { Fatah) }\end{array}$ & $\begin{array}{l}\text { a. } \text { RPP } \\
>\text { Perbaiki penulisan } \\
>\text { Model dan metode } \\
\text { pembelajaran diperjelas } \\
\text { b. } \text { LKS } \\
>\text { Perbaiki penulisan kalimat } \\
\text { Perbesar kolom untuk siswa } \\
\text { menulis jawaban } \\
\\
\text { c. Soal Posttest } \\
\text { Perbaiki kisi-kisi soal }\end{array}$ \\
\hline $\begin{array}{c}\text { Tia Utari, S.Pd } \\
\text { (Guru Mata Pelajaran Matematika) }\end{array}$ & $\begin{array}{l}\text { a. RPP } \\
\text { Sudah Baik } \\
\text { b. LKS } \\
\text { Sudah Baik } \\
\text { c. Soal Posttest } \\
\text { Perbaiki skor untuk hasil } \\
\text { penyelesaian soal cerita }\end{array}$ \\
\hline
\end{tabular}

Dari hasil validasi ini, disimpulkan bahwa RPP, Lembar diskusi kelompok (LKS) dan soal posttest ini telah memenuhi kriteria valid dan siap untuk diterapkan pada sampel yang telah dipilih.

\section{b. Hasil Validasi kepada Siswa}

Setelah divalidasi oleh para validator, soal post-test yang berjumlah 5 soal tersebut diuji cobakan kepada 10 siswa kelas IX A untuk mengetahui apakah butir soal tersebut sudah memenuhi kualitas soal yang baik atau belum. Adapun alat yang digunakan dalam pengujian 
analisis uji coba instrument meliputi analisis validitas tes dan reliabilitas tes.

Dari hasil uji coba validasi dan perhitungan korelasi didapat

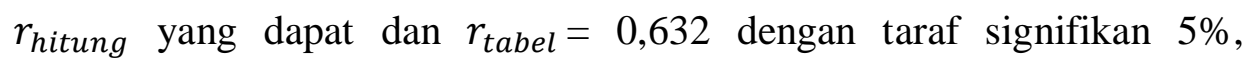
$r_{\text {hitung }}>r_{\text {tabel }}$ untuk soal no 1 sampai soal nomor 4. Sedangkan untuk soal no $5 \quad r_{\text {hitung }}<r_{\text {tabel }}$, maka disimpulkan bahwa soal post-test untuk soal nomor 1 sampai nomor 4 dinyatakan valid dan dapat digunakan. Sedangkan untuk uji reabilitas dengan menggunakan rumus Alpha diperoleh hasil perhitungan harga $r_{\text {hitung }}$ sebesar 0,7503 lebih besar dari $r_{\text {tabel }}$ yaitu 0,632 dengan jumlah $n=5$ untuk taraf signifikan $\alpha=$ $5 \%$ atau $r_{\text {hitung }}>r_{\text {tabel }}$ sehingga dapat disimpulkan soal tes akhir adalah reliabilitas.

\section{B. Hasil Analisis Data Penelitian}

\section{Uji Normalitas}

Uji normalitas ini menggunakan uji Liliefors yang pada dasarnya menggunakan data dasar yang belum diolah dalam tabel distribusi frekuensi seperti sebelumnya pada Uji Chi-Squares. Untuk kelas ekperimen nilai kritis

L untuk Uji Lilliefors $(\alpha=0,05)=\frac{0,886}{\sqrt{32}}=0,156$ didapat $\mathrm{L}_{0}=0,1357$ dengan $\mathrm{n}=32$ dan taraf nyata $\alpha=0,05$, dari daftar nilai kritis L untuk Uji Lilliefors didapat $\mathrm{L}=0,156$ yang lebih besar dari $\mathrm{L}_{0}=0,1357$ sehingga kesimpulannya menunjukkan data hasil posttest dari kelas eksperimen berdistribusi normal. Sedangkan kelas kontrol Nilai Kritis L untuk Uji Lilliefors $(\alpha=0,05)=\frac{0,886}{\sqrt{34}}$ $=0,159$ didapat $\mathrm{L}_{0}=0,1132$ dengan $\mathrm{n}=31$ dan taraf nyata $\alpha=0,05$, dari daftar nilai kritis $\mathrm{L}$ untuk Uji Lilliefors didapat $\mathrm{L}=0,159$ yang lebih besar dari $\mathrm{L}_{0}=0,1132$ sehingga kesimpulannya menunjukkan data hasil posttest dari kelas kontrol berdistribusi normal.

\section{Uji Homogenitas}

Uji Homogenitas bertujuan untuk mengetahui apakah sampel homogen

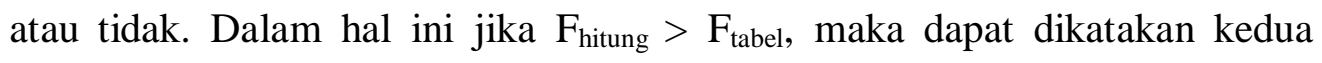
kelompok mempunyai kesamaan varians/homogen, dengan varians kelas eksperimen 54,56 dan varians kelas kontrol 56,95 serta $d$ kembilang $=(31-$ 
1) $=30$ dan $d k$ penyebut $=(32-1)=30$. Dari kedua varians diperoleh $F_{\text {hitung }}=$ 1,422 sedangkan derajat kebebasan untuk pembilang 33 dan penyebut 31 dengan taraf nyata $5 \%$, maka $F_{\text {tabel }}$ diperoleh dengan $F_{t}=2,04$ karena $F_{\text {hitung }} \leq$ $\mathrm{F}_{\text {tabel }}$ sehingga $\mathrm{H}_{0}$ diterima, dengan demikian sampel yang digunakan dalam penelitian merupakan sampel yang homogen.

\section{Uji Hipotesis}

Hasil perhitungan menunjukan bahwa data hasil belajar matematika kelas eksperimen dan kontrol berdistribusi normal dan homogen. Diketahui $d k=32+31-2=61$ dengan $\alpha=5 \%$ maka $t_{\text {tabel }}=1,999$ bdari hasil di atas diperoleh bahwa $t_{\text {hitung }}=7,539$ sehingga $t_{\text {hitung }}>t_{\text {tabel }}$ yaitu 7,539 $>1,999$ maka dengan demikian pengujian hipotesis tersebut $H_{o}$ ditolak dan $H_{a}$ diterima yang bearti dapat disimpulkan bahwa ada pengaruh model cooperative learning tipe cooperative integrated reading and composition terhadap kemampuan menyelesaikan soal cerita kelas VIII di MTs Ahliyah 1 Palembang.

\section{Pembahasan hasil penelitian}

\section{Hasil Penelitian}

Berdasarkan hasil postest siswa diperoleh nilai rata-rata kelas eksperimen yaitu 88 sedangkan kelas kontrol yaitu 72,66. Dimana skor tertinggi kelas eksperimen 98, skor terendah 73. Sedangkan skor tertinggi kelas kontrol 86 dan skor terendah 45. Berikut dapat dilihat hasil postest pada tabel dibawah ini:

Selanjutnya untuk mengetahui kemampuan siswa dalam menyelesaikan setelah proses pembelajaran berlangsung pada kelas eksperimen, berikut rangkuman hasil perhitungan berdasarkan persentase kategori penilaian:

Tabel 3.

Persentase Hasil Menyelesaikan soal cerita Kelas Eksperimen

\begin{tabular}{|c|c|c|c|}
\hline Nilai Siswa & Kategori & Frekuensi & $\begin{array}{c}\text { Persentase } \\
(\mathbf{\%})\end{array}$ \\
\hline $81-100$ & Sangat Baik & 26 & 81 \\
\hline $66-80$ & Baik & 6 & 19 \\
\hline $56-65$ & Cukup & 0 & 0 \\
\hline $41-55$ & Kurang & 0 & 0 \\
\hline
\end{tabular}




\begin{tabular}{|c|c|c|c|}
\hline $0-40$ & Sangat Kurang & 0 & 0 \\
\hline \multicolumn{2}{|c|}{ Jumlah } & $\mathbf{3 2}$ & $\mathbf{1 0 0}$ \\
\hline
\end{tabular}

Keterangan :

$$
\text { Persentase }=\frac{\text { Frekuensi }}{\text { Jumlah }} \times 100 \%
$$

Tabel 4. Persentase Hasil Menyelesaikan soal cerita Kelas Kontrol

\begin{tabular}{|c|c|c|c|}
\hline Nilai Siswa & Kategori & Frekuensi & $\begin{array}{c}\text { Persentase } \\
(\mathbf{\%})\end{array}$ \\
\hline $81-100$ & Sangat Baik & 4 & 13 \\
\hline $66-80$ & Baik & 24 & 77 \\
\hline $56-65$ & Cukup & 0 & 0 \\
\hline $41-55$ & Kurang & 3 & 10 \\
\hline $0-40$ & Sangat Kurang & 0 & 0 \\
\hline \multicolumn{2}{|r|}{ Jumlah } & $\mathbf{3 1}$ & $\mathbf{1 0 0}$ \\
\hline
\end{tabular}

Keterangan :

$$
\text { Persentase }=\frac{\text { Frekuensi }}{\text { Jumlah }} \times 100 \%
$$

\section{Pembahasan}

Penelitian eksperimen ini meneliti tentang ada atau tidaknya pengaruh perlakuan, dengan cara memberikan perlakuan tertentu pada kelas eksperimen dan menyediakan kelas kontrol sebagai perbandingan. Setelah menentukan kelas eksperimen dan kelas kontrol, peneliti memberikan perlakuan. Pada kelas eksperimen diberikan perlakuan berupa pembelajaran dengan menggunakan model pembelajaran kooperatif tipe Cooperatif Integrated Reading and Composition (CIRC) dan untuk pembelajaran pada kelas kontrol dilakukan secara konvensional. Setelah diberikan perlakuan, selanjutnya diberikan posstest untuk mengetahui apakah ada pengaruh kemampuan siswa dalam menyelesaikan soal cerita yang telah diberikan perlakuan. Posstest pada pertemuan ke enam.

Hasil penelitian menunjukkan adanya perbedaan perolehan nilai siswa pada kelas eksperimen dan kelas kontrol. Hal ini terlihat pada rekap nilai siswa. Setelah perlakuan pada kelas eksperimen, diperoleh rata-rata posstest 88 dengan nilai tertinggi 98 dan nilai terendah 73. Sedangkan pada kelas kontrol, diperoleh rat-rata posstest 72,64 dengan nilai tertinggi 86 dan nilai terendah 45 . Hal ini menunjukkan bahwa rata-rata kemampuan menyelesaikan soal cerita yang diberikan perlakuan dengan menggunakan model pembelajaran kooperatif tipe Cooperative Integrated Reading and Composition lebih tinggi dan berpengaruh 
dari pada rata-rata kemampuan menyelesaikan soal cerita yang diajarkan secara konvensional.

Pada kelas eksperimen, untuk 4 butir soal posttest yang diberikan indikator pertama yaitu memahami masalah rata-rata 90,8\% siswa yang berhasil, indikator yang kedua yaitu membuat model matematika rata-rata 94\% yang berhasil, indikator ketiga yaitu memilih strategi pemecahan rata-rata $90 \%$ yang berhasil dan dalam indikator keempat yaitu memeriksa kembali rata-rata 80,8\% siswa yang berhasil. Maka dapat disimpulkan bahwa rata-rata siswa kelas eksperimen mampu dalam menyelesaikan soal cerita dengan benar.

Sedangkan pad indikator ke kelas kontrol, indikator 4 yaitu memeriksa kembali jawaban masih berada pada skor kemampuan yang terendah dibandingkan dengan indikator lainnya, hanya 47,5\% siswa yang berhasil pada indikator ini. Hasil jawaban siswa pada indikator ini rata-rata hanya menuliskan kesimpulan tanpa mengecek hasil jawaban yang telah diperoleh. Hal ini dikarenakan siswa berpikir jawaban yang telah diperoleh dari mensubtitusikan nilai kedalam persamaan sudah benar tanpa harus memeriksa kembali. Sedangkan untuk indikator 1 yaitu memahami masalah berada pada skor kemampuan terendah kedua setelah indikator memeriksa kembali. Pada indikator ini hanya $73,5 \%$ siwa yang berhasil memecahkan masalah. Letak kesalahan untuk indikator ini yaitu salah dalam menuliskan yang diketahui dari soal. Perbedaan kelas eksperimen dengan kelas kontrol dalam menyelesaikan soal cerita dapat dilihat pada gambar berikut:

1. Irin, tata, tika dan tiwi pergi bersama ke tempat pameran di BKB. Sesampainya disana tata membeli 2 jilbab dan 3 bros seharga $R p$ 45.000,00. Irin membeli 2 jilbab dan 2 bros seharga Rp. 40.000,00. Sedangkan Tiwi membeli 1 bros dan 3 kaos kaki dengan harga Rp 15.000,00. Jika Tika membeli 1 jilbab dan 2 bros tersebut dengan uang sebesar Rp. 50.000,00. Berapakah besar uang kembaliannya Tika?

Gambar 1. Soal No 1

Jawaban siswa kurang teliti dalam membuat pernyataan: 


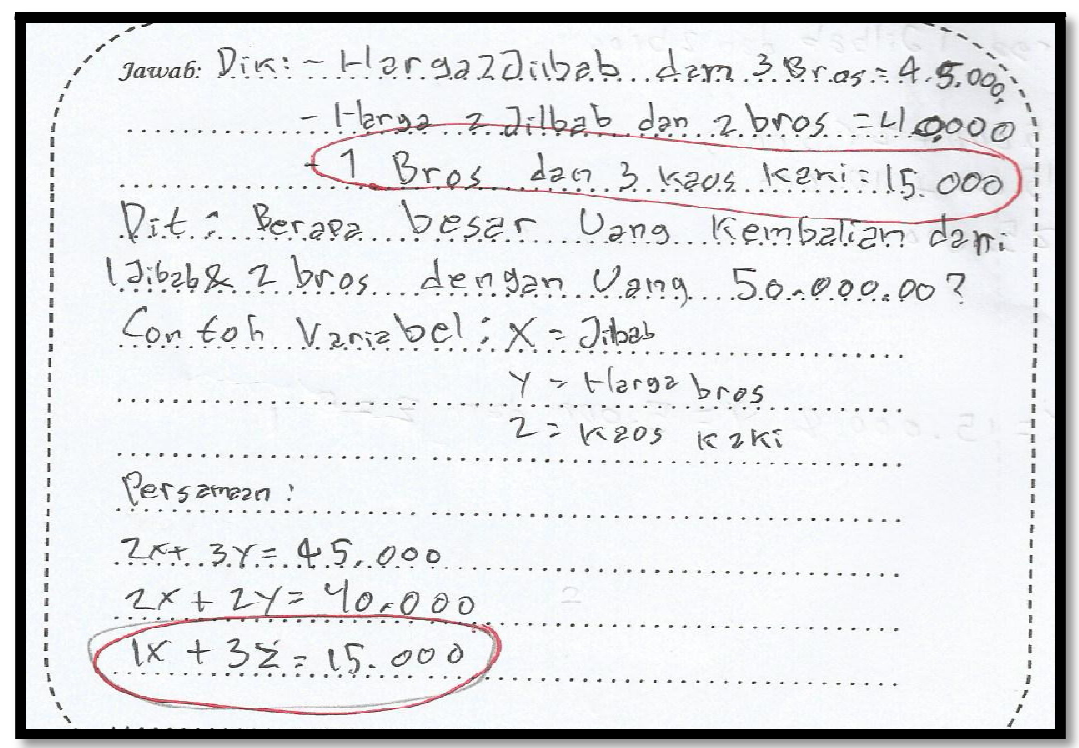

Gambar 2. Jawaban siswa kelas kontrol

Jawaban siswa yang tepat dalam menyelesaikan masalah:

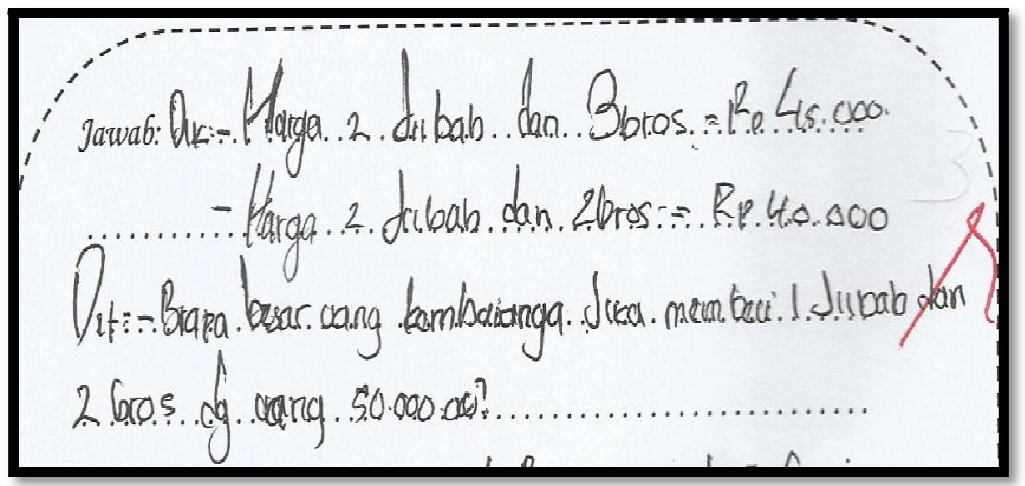

Gambar 3. Jawaban siswa kelas eksperimen

Untuk soal nomor 1 rata-rata kelas eksperimen yaitu 91 lebih besar dibandingkan rata-rata kelas kontrol yaitu 89,5. Hal ini berarti kemampuan keempat indikator kelas eksperimen lebih baik dari pada kelas kontrol. Hal ini dikarenakan siswa kurang teliti dalam membuat pernyataan apa yang diketahui dan ditanyakan.

2. Andi membeli 2 sandal dan 1 sepatu di pasar dengan harga Rp 200.000,00. Sesampai dirumah ternyata salah satu sandalnya kebesaran, sehingga ia momutuskan untuk menukarkan satu sandal dengan sepatu. Karena sepatu lebih mahal maka ia harus mombayar lagi Rp 50.000,00. Harga masingmasing sandal dan sepatu adalah?

Gambar 4. Soal No 2 
Jawaban siswa yang tidak tepat dalam menyelesaikan soal cerita

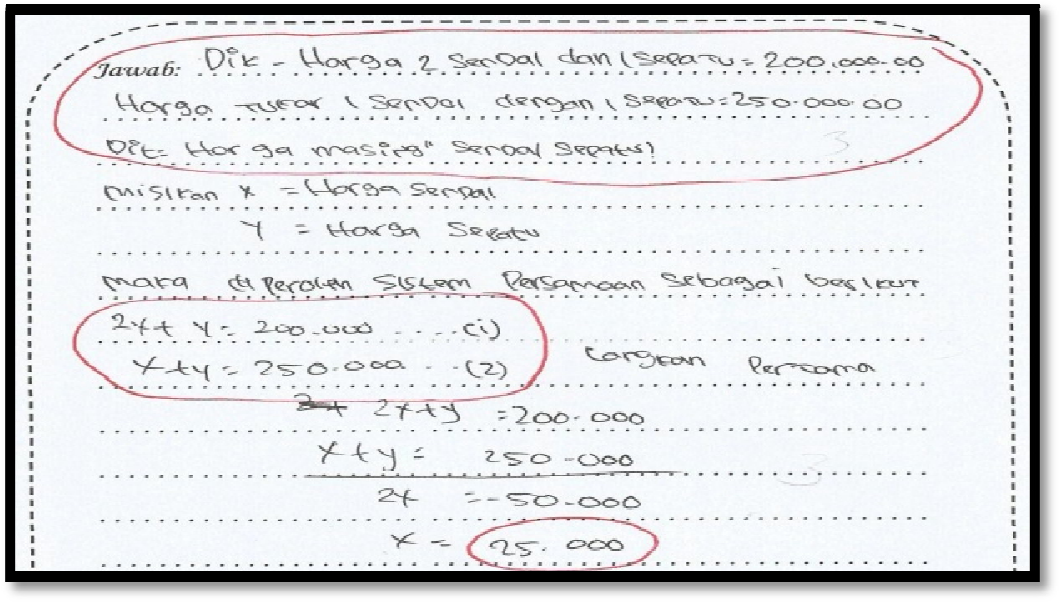

Gambar 5. Jawaban siswa kelas kontrol

Jawaban siswa yang tepat dalam memecahkan masalah:

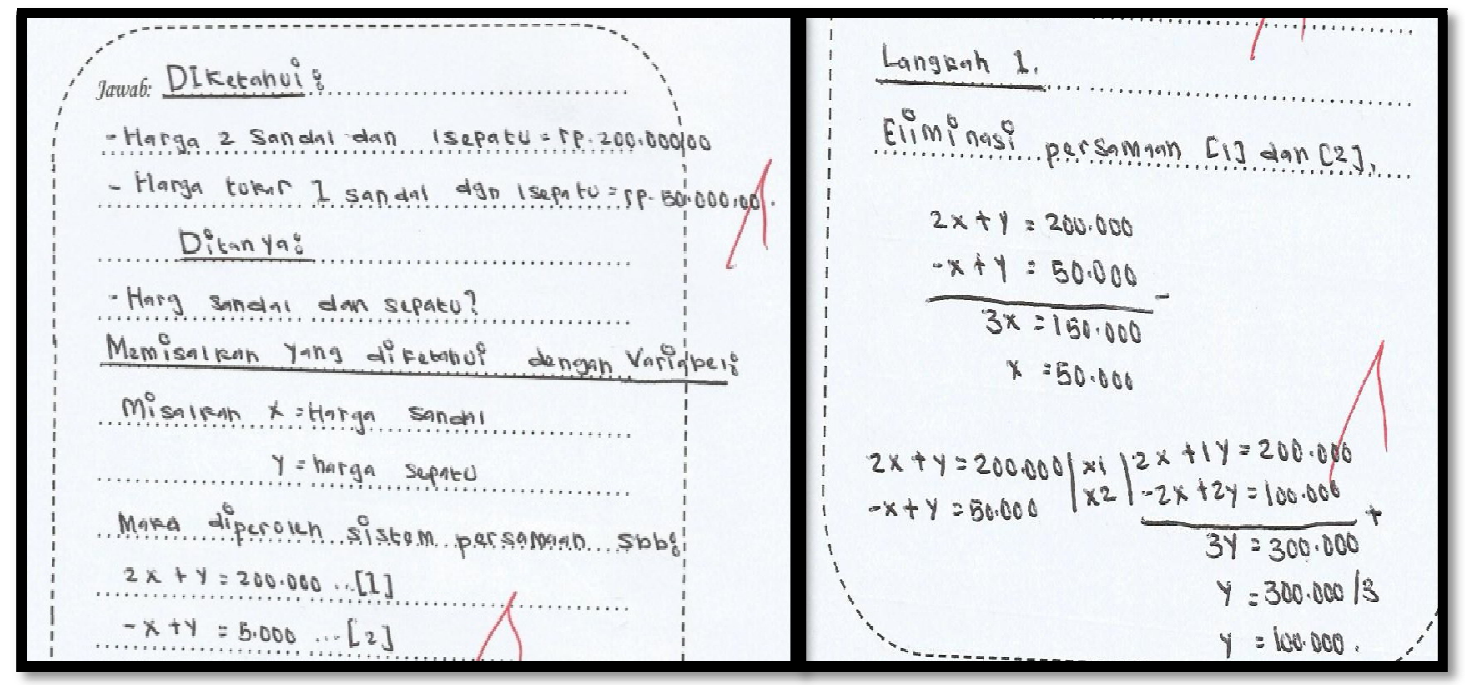

Gambar 6. Jawaban siswa eksperimen

Untuk soal no. 2, kemampuan pemecahan masalah yang diukur adalah keempat indikator pemecahan masalah yang telah disebutkan. Rata-rata kelas eksperimen yaitu 89,3 sedikit lebih besar dari rata-rata kelas kontrol yaitu 87,3. Aspek memahami masalah rata-rata siswa kelas kontrol masih banyak yang salah dalam memahaminya, hal ini berdampak pada perhitungan hasil yang menyebabkan siswa mendapatkan nilai kecil.. Namun ada beberapa siswa yang belum tepat menyelesaikannya. Dari gambar di atas dapat di lihat bahwa dalam indikator memahami masalah soal berbentuk cerita kelas eksperimen lebih baik dari kelas kontrol. Jika sudah salah dalam menentukan variabel yang diketahui 
dan ditanyakan, selanjutnya akan salah pula dalam membuat model matematikanya. Hal ini berdampak pada perhitung hasil yang menyebabkan siswa mendapat nilai rendah.

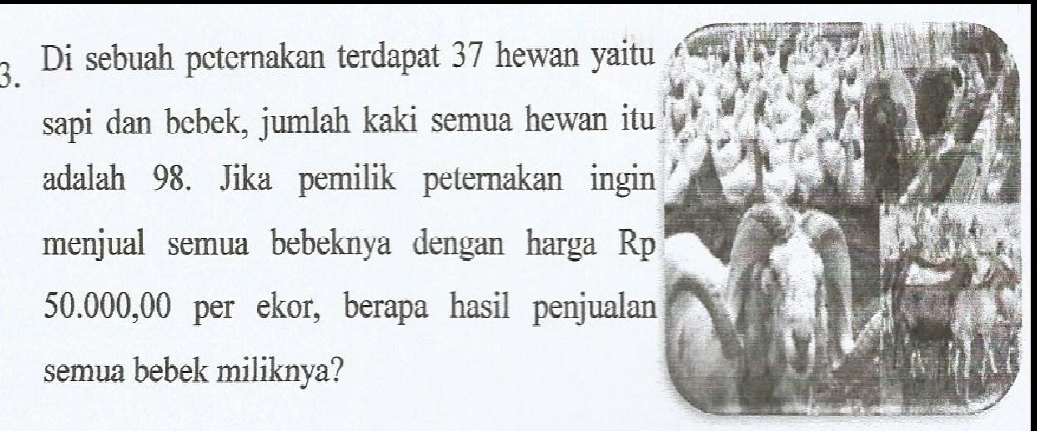

Gambar 7. Soal No 3

Jawaban siswa yang salah dalam memilih strategi penyelesaian:

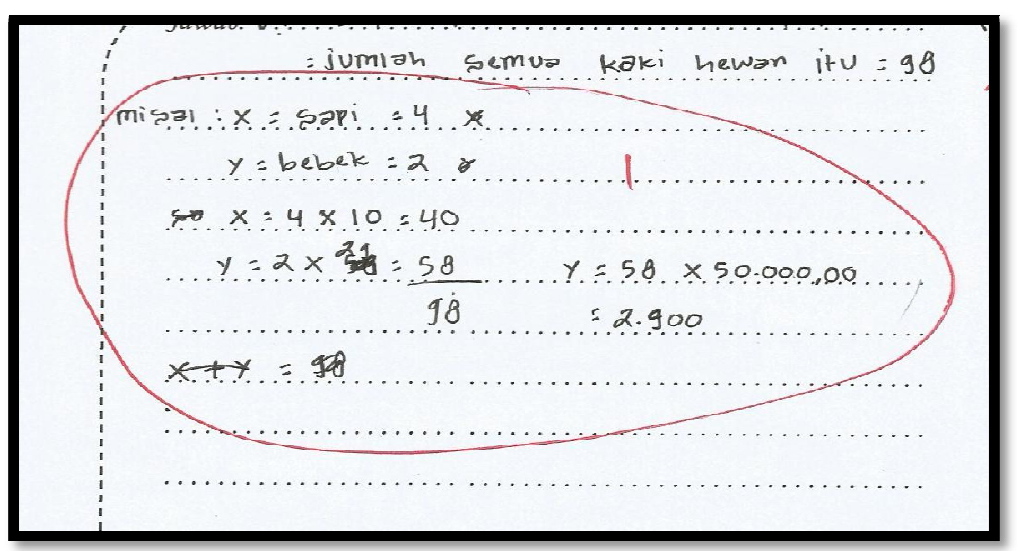

Gambar 8. Hasil jawaban siswa kelas kontrol

Jawaban siswa yang tepat dalam memecahkan masalah:

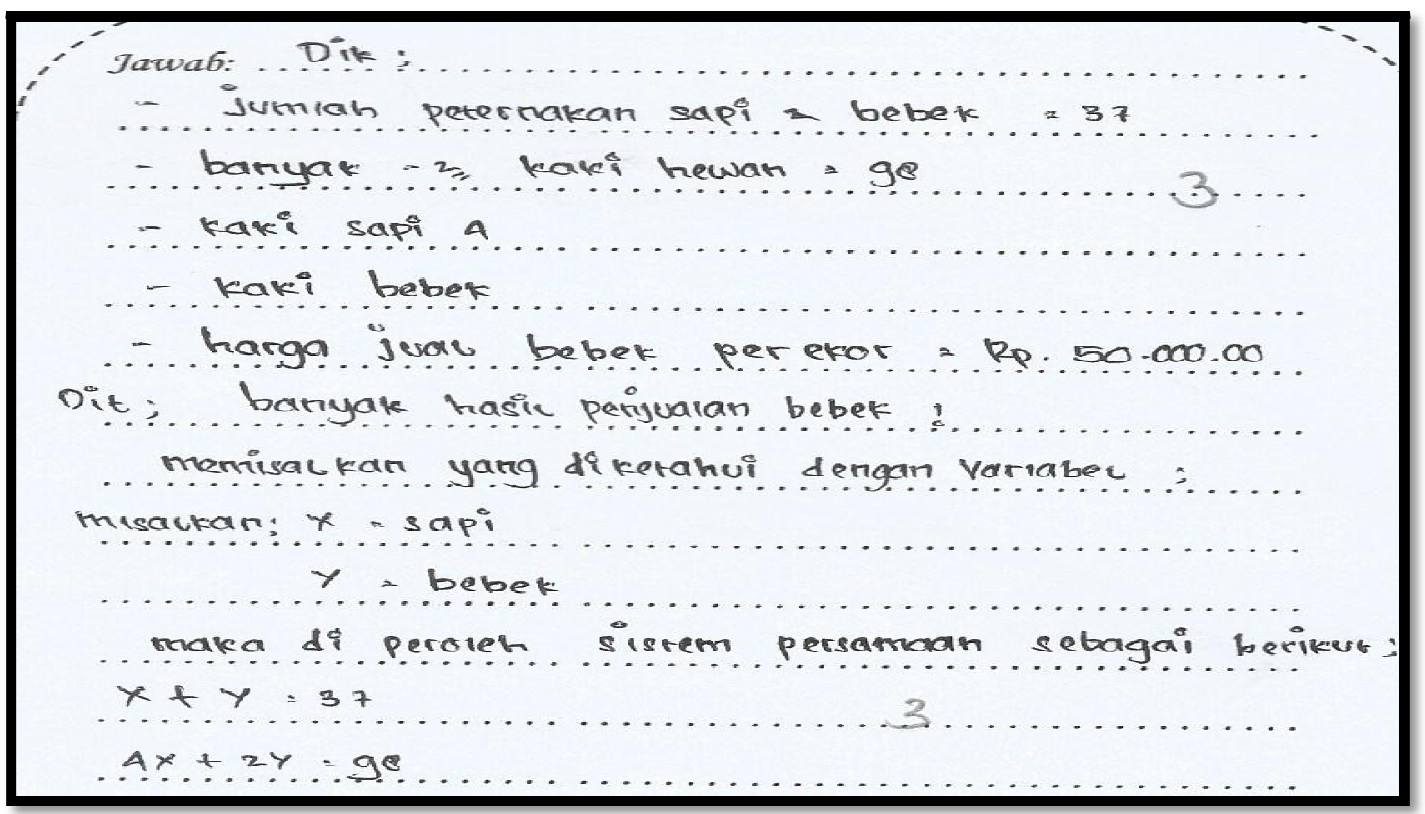




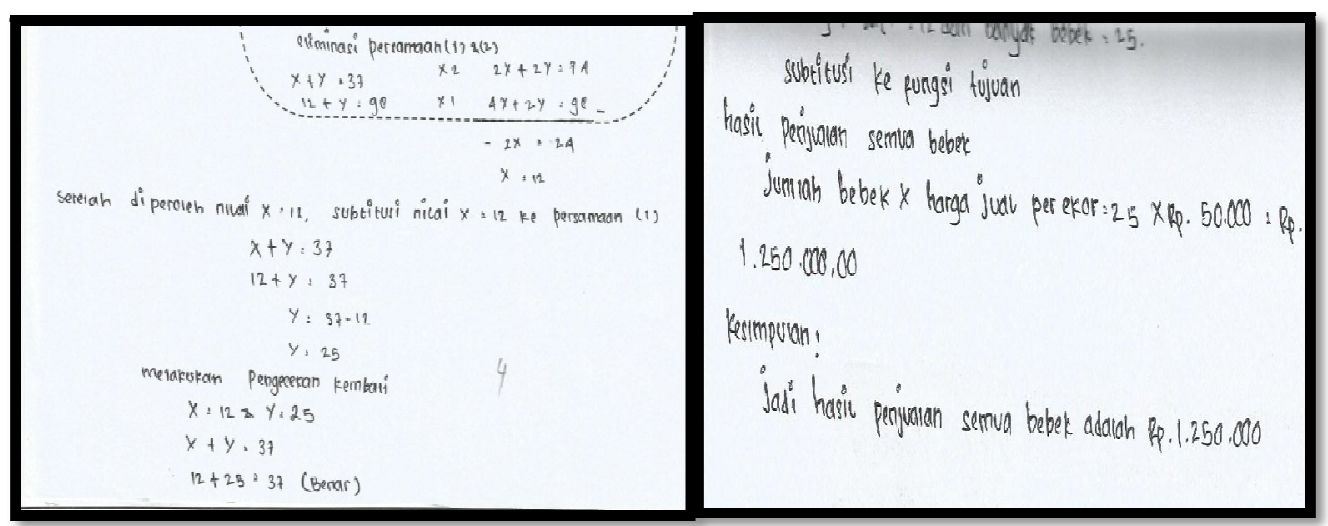

Gambar 9. Hasil jawaban siswa

Untuk soal no 3, rata-rata kelas eksperimen yaitu 86,3 lebih besar dari ratarata kelas kontrol yaitu 66. rata-rata siswa kelas kontrol dan eksperimen sudah mampu memahami masalah yang diberikan, akan tetapi pemilihan strategi penyelesaian tidak tepat sehingga tidak dapat diselesaikan.

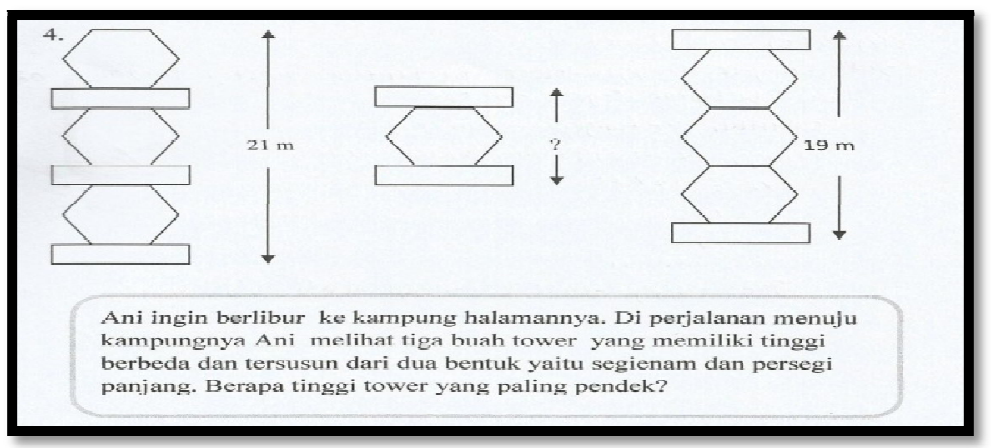

Gambar 10. Soal No 4

Jawaban siswa yang tepat dalam menyelesaikan masalah:

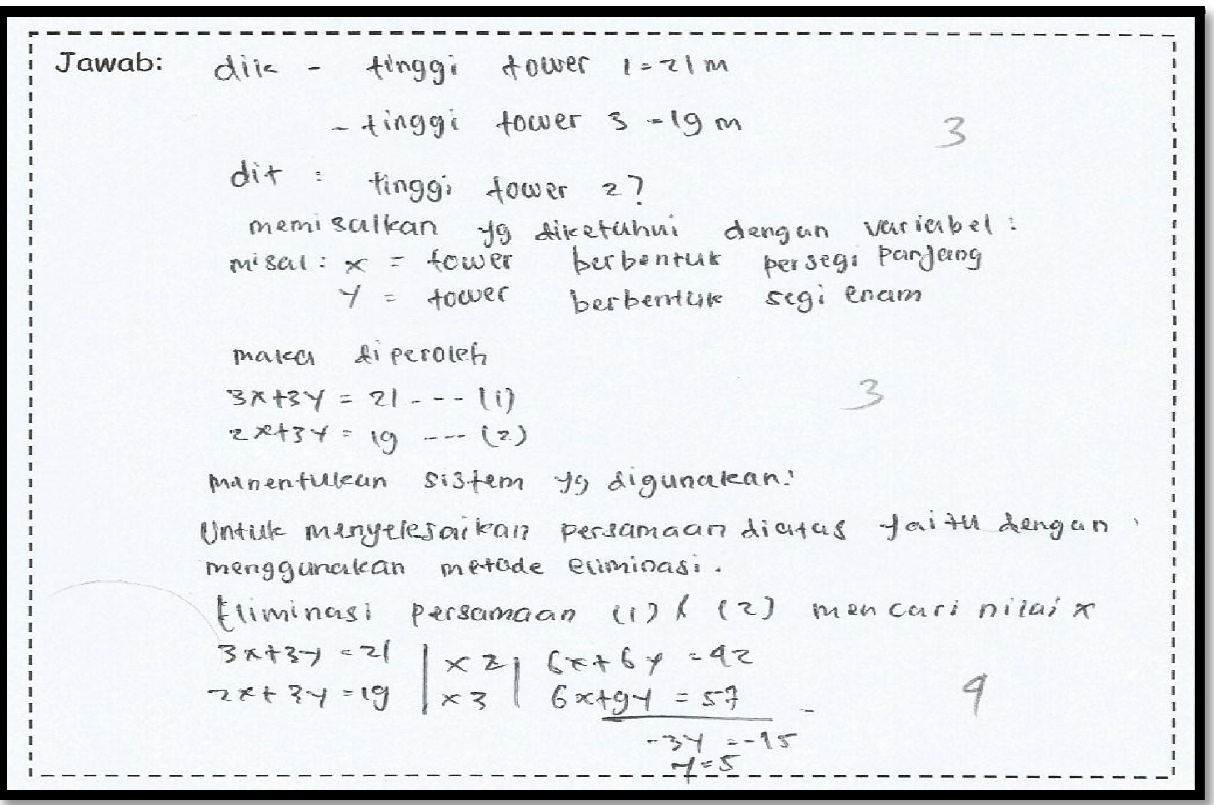




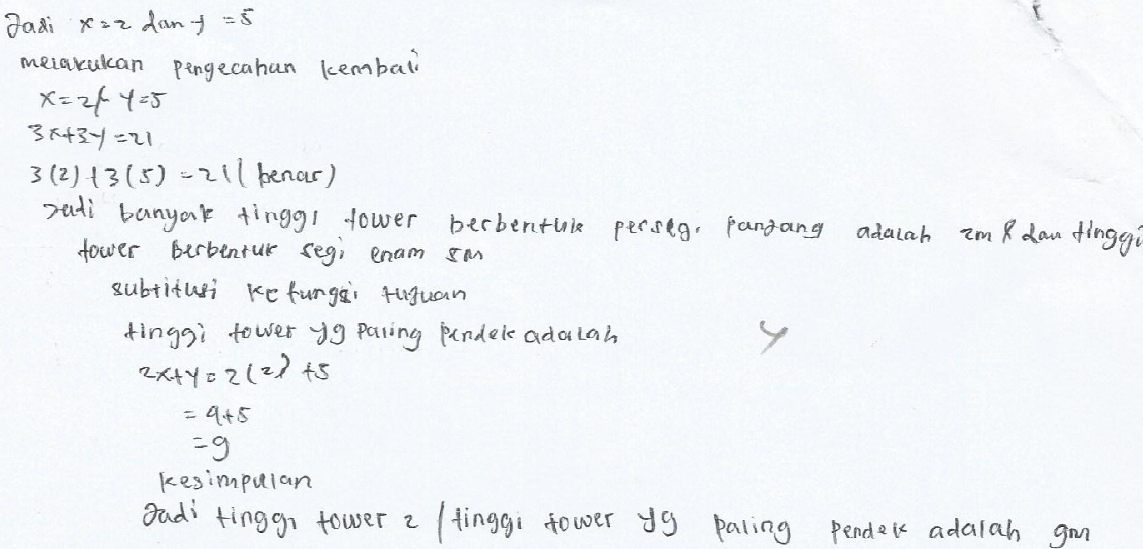

Gambar 11. Hasil jawab siswa

Untuk soal no 4, kemampuan yang diukur adalah keempat indikator yang telah disebutkan. Rata-rata kelas eksperimen yaitu 89 lebih besar dari rata-rata kelas kontrol yaitu 54. rata-rata siswa kelas kontrol masih banyak yang tidak memahami masalah yang diberikan.

\section{KESIMPULAN DAN SARAN}

\section{a. Kesimpulan}

Berdasarkan hasil penelitian yang dilakukan di kelas VII MTs Ahliyah 1 Palembang dengan materi sistem persamaan linear dua variabel selama 5 kali tatap muka dan 1 kali Post-test, diperoleh kesimpulan bahwa terdapat pengaruh model pembelajaran kooperatif tipe Cooperative Integrted Reading and Composition (CIRC) terhadap kemampuan menyelesaikan soal cerita dibandingkan pembelajaran dengan metode ceramah, hal ini didapat melalui hasil tes akhir (post-test) siswa. Hasil rata-rata post-test siswa kelas eksperimen yang menggunakan model pembelajaran kooperatif tipe Cooperative Integrted Reading and Composition (CIRC) lebih tinggi dari pada kelas kontrol yang menggunakan metode ceramah yaitu kelas eksperimen 88 dan kelas kontrol 72,64. Dari hasil uji $\mathrm{t}$ didapat $\mathrm{t}_{\text {hitung }}>\mathrm{t}_{\text {tabel }}$ yaitu $\mathrm{t}_{\text {hitung }}=7,539$ dan $\mathrm{t}_{\text {tabel }}=$ 1,999 dengan taraf signifikan $5 \%$ dari pengujian hipotesis $\mathrm{H}_{\mathrm{a}}$ diterima yang bearti ada pengaruh model pembelajaran kooperatif tipe Cooperative Integrted 
Reading and Composition (CIRC) terhadap kemampuan menyelesaikan soal cerita materi SPLDV kelas VIII di MTs Ahliyah 1 Palembang.

Adapun beberapa kendala yang ditemukan ketika proses pembelajaran berlangsung dikarenakan siswa belum terbiasa dalam menyesuaikan diri dengan adanya penerapan model cooperative learning tipe Cooperative Integrated Reading and Composition (CIRC). hal ini berakibat pada kurangnya alokasi waktu untuk pembelajaran dengan model pembelajaran ini Karena itu perlu mengkondisikan siswa dalam kelompok-kelompok dan membimbing siswa pada saat melakukan diskusi. Namun seiring waktu siswa akan terbiasa dengan penerapan model pembelajaran ini, sehingga kendala tersebut dapat diatasi.

\section{b. Saran}

Berdasarkan kesimpulan di atas, melihat dari kendala yang dialami peneliti pada saat melakukan penelitian dapat disajikan sebagai saran yang mana berguna untuk perbaikan penelitian selanjutnya, yaitu:

1. Diharapkan kepada peneliti selanjutnya untuk menilai aktivitas siswa dengan menggunakan lembar aktivitas agar keaktifan siswa dengan menggunakan model ini bisa terlihat.

2. Penggunaan alokasi waktu dan kondisi kelas harus benar-benar dikondisikan dan diperhitungkan sesuai jam pelajaran yang tersedia agar setiap langkah-langkah pembelajaran dari model ini dapat dijalankan dengan baik.

\section{DAFTAR PUSTAKA}

Arikunto, Suharsimi. 2010. Prosedur Penelitian Suatu Pendekatan Praktik. Jakarta. Rineka Cipta.

Arikunto, Suharsimi. 2013. Prosedur Penelitian. Jakarta. Rineka Cipta.

Departemen Pendidikan Nasional Direktorat Jendral Manajemen Pendidikan Dasar dan Menengah Direktorat Pembinaan SMP. 2006. Grand Design Penuntasan Wajib Belajar 9 Tahun 2006-2009. Diakses 6 April 2016 (online) (http://www.dikdasmen.org/files/grandisain-0806.htm).

Huda, Miftahul. 2014. Model- Model Pengajaran dan Pembelajaran. Yogyakarta. Pustaka Pelajar.

Hudojo,H. 2005. Pengembangan Kurikulum dan Pembelajaran Matematika edisi revisi II. Malang: Universitas Negeri Malang (UM Press). 
Kesumawati, Nila. 2010. Peningkatan Kemampuan Pemahaman, Pemecahan dan Disposisi Matematis Siswa SMP Melalui Pendekatan Pendidikan Matematika Realistik. Disertasi Doktor pada Pasca Sarjana UPI Bandung: tidak diterbitkan.

Slavin, Robert E. 2005. Cooperative Learning. Bandung. Nusa Media.

Sugiyono. 2009. Metode Penelitian Kuantitatif Kualitatif dan R\&D. Bandung. Alfabeta. 